KRAEMISR, S. (1993) The case for a multi-disciplinary child and adolescent mental health community service. Discussion paper, avallable from author, c/o Tavistock Clinic, London.

KURTZ, Z. (1992) With Health in Mind. Mental health care for children and young people. London: Action for Sick Children.

LGHT, D. \& BAnEY, V. (1993) Pound foolish. Health Services Journal, 108, (11 February). 16-18.

RoYAl COUBGe of PSYCHITRISTS (1994) Newsletter of the Child and Adolescent Section. Summer.

SLADE, M. (1994) Needs assessment. Brttish Joumal of Psychiatry. 166, 293-296.
StzVEnS, A. \& GABBAY, J. (1991) Needs assessment needs assessment. Health Trends, 23, 20-23.

Vanstrazlen, M. \& CotrReu, D. (1994) Child and adolescent mental health services: purchasers knowledge and plans. British Medical Journal, 309. 259-261.

R. P. W. Fry, Senior Registrar, Department of Psychological Medicine, The Hospitals for Sick Children, Great Ormond Street, London WC1N 3JH.

\title{
Trust and control
}

\section{Lary Culliford}

Where human relationships are concerned, issues of trust and control go together. Where professional relationships are concerned. these issues require special attention.

I will let you take control, give me orders, make directions and offer advice - if I trust you.

I will let you take control, give me orders, make directions and offer advice to the extent that I trust you. The level of my trust may fluctuate. You are wise to pay attention to this. When I trust you absolutely, you may do with me as you will.

It may be best when there is mutual trust. Control may then be shared. Sometimes I will make decisions affecting us both. Sometimes you will make such decisions. Sometimes we will make them together.

When I want to take control, to make decisions and see them carried through. I will endeavour to gain and retain your confidence, hence your respect and esteem. (Only later perhaps, when trust is assured, will I hope for and anticipate your affection.)
I will endeavour to be trustworthy. This involves keeping you informed and telling you no lies. I will hope for the same honesty and trustworthiness from you.

I recognise how difficult it is to provide these conditions. I will strive towards patience, tolerance, understanding and forglveness in our dealings. I will hope for the same patience. tolerance, understanding and forgiveness from you.

Where human failings arise, I will endeavour to put my trust in a just and benevolent universe. If I go about my business faithfully, may I confidently anticipate the rewards of my trust, faith and fidelity? On the deepest and most earnest reflection, I do not doubt this so far... and give thanks.

\section{Larry Culliford, Consultant Psychiatrist, Hove Community Mental Health Centre, Hove BN3 4AG}

